RESIDENT

\& FELLOW

SECTION

Section Editor

Mitchell S.V. Elkind,

MD, MS

Parayil Sankaran Bindu, MD

Jerry M.E. Kovoor, MD

Rita Christopher, MD

Address correspondence and reprint requests to Dr. P.S.

Bindu, Department of

Neurology, NIMHANS,

Bangalore, India

drpsbindu@yahoo.co.in

\section{Teaching NeuroImages: \\ MRI in methylmalonic acidemia}

Figure MRI: Axial (A, black arrows) and coronal (B, white arrows) T2W MRI demonstrating bilateral symmetric hyperintensity involving globus pallidi

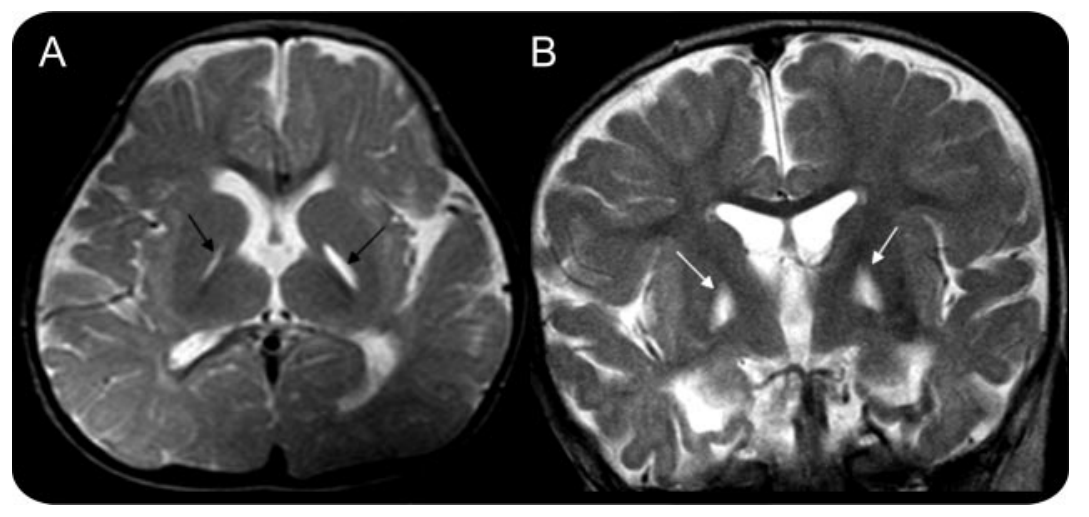

An 18-month-old girl presented with recurrent episodes of encephalopathy, starting from the third postnatal day, and delayed development. Her parents were nonconsanguineous. She had microcephaly, generalized hypotonia, brisk stretch reflexes, extensor plantar response, choreiform movements, and dystonia of hands and feet. Evaluation showed metabolic acidosis and hyperammonemia. Tandem mass spectroscopy at age 18 months revealed elevated methylmalonyl carnitine $(2.68 \mu \mathrm{mol} / \mathrm{L}$; normal $0.00-1.02)$ and propionyl carnitine $(16.73 \mu \mathrm{mol} / \mathrm{L}$; normal $0.08-6.50)$, indicating methylmalonic acidemia (MMA). MRI at the same time showed bilateral symmetric T2 hyperintensities involving globus pallidi (figure, A and B). Selective necrosis of the globus pallidus is an important MRI finding in MMA. ${ }^{1,2}$ Differential diagnoses include propionic acidemia, pyruvate dehydrogenase deficiency, kernicterus, and carbon monoxide poisoning. Management consists of protein restricted diet, carnitine, and parenteral vitamin B12.

\section{REFERENCES}

1. Yeçsildağ A, Ayata A, Baykal B, et al. Magnetic resonance imaging and diffusion-weighted imaging in methylmalonic acidemia. Acta Radiol 2005;46:101-103.

2. Michel SJ, Given CA 2nd, Robertson WC Jr. Imaging of the brain, including diffusion-weighted imaging in methylmalonic acidemia. Pediatr Radiol 2004;34:580-582. 


\title{
Neurology
}

\author{
Teaching NeuroImages: MRI in methylmalonic acidemia \\ Parayil Sankaran Bindu, Jerry M.E. Kovoor and Rita Christopher \\ Neurology 2010;74;e14 \\ DOI 10.1212/WNL.0b013e3181cc0b7b
}

This information is current as of January 25, 2010

\section{Updated Information \&}

Services

References

Subspecialty Collections

Permissions \& Licensing

Reprints including high resolution figures, can be found at:

http://n.neurology.org/content/74/4/e14.full

This article cites 2 articles, 0 of which you can access for free at: http://n.neurology.org/content/74/4/e14.full\#ref-list-1

This article, along with others on similar topics, appears in the following collection(s):

All Pediatric

http://n.neurology.org/cgi/collection/all_pediatric

Amino acid

http://n.neurology.org/cgi/collection/amino_acid

Metabolic disease (inherited)

http://n.neurology.org/cgi/collection/metabolic_disease_inherited

MRI

http://n.neurology.org/cgi/collection/mri

Information about reproducing this article in parts (figures,tables) or in its entirety can be found online at:

http://www.neurology.org/about/about_the_journal\#permissions

Information about ordering reprints can be found online:

http://n.neurology.org/subscribers/advertise

Neurology ${ }^{\circledR}$ is the official journal of the American Academy of Neurology. Published continuously since 1951, it is now a weekly with 48 issues per year. Copyright. All rights reserved. Print ISSN: 0028-3878. Online ISSN: 1526-632X.

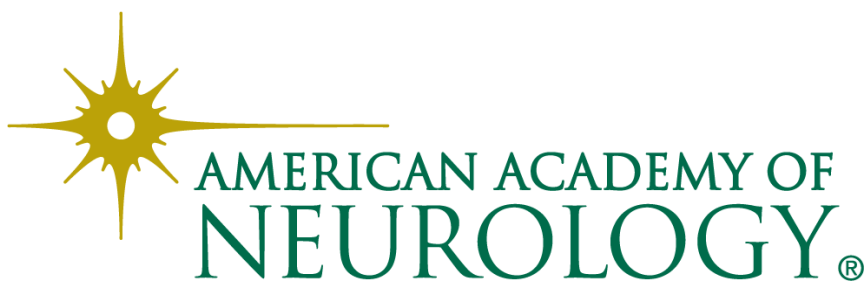

